\title{
Using SEM (Structural Equation Modeling) to Examine the Effects of the Body's Image on what Women Like and Choose in Clothing ${ }^{1}$
}

\author{
Berna Yildirim Artac \\ Gazi University, Student of PhD Ankara Turkey
}

Fatma Koc

Assoc. Prof. Dr., Gazi University, Faculty of Art and Design, Department of Fashion Design, Golbası / Ankara/ Turkey

\begin{abstract}
For women the body is an important concept in clothing aesthetics. Body image is an important factor influencing what women like in clothing and what they choose to wear.In this study, which has been prepared with the aim of stressing the importance of the relationship between "Clothing Preference" and "Body Image", women's ability to minimize the difference between their ideal appearance and their actual appearance, as well as their ability to possess a good self-image and powerful self-confidence, have been studied.Structural Equation Modelling (SEM) was used in this study. The sample is 150 women aged 18-50 within the Konya Province in Turkey limits.

The research concluded that while there was a relationship between the visual and verbal clothing choices for the women in the sample group, there was less of a match among their visual choices.
\end{abstract}

Keywords: Body satisfaction, image, clothing, SEM, women

\section{Introduction}

The rapidly changing field of fashion today, while accompanied by the other gains in fashion trends, is the reason why the body and concepts relating to the body are continually a part of current life. For women in particular the increase in the importance of such reasons as outward appearance, aesthetic concerns, status and social acceptance plus the

${ }^{1}$ This essay was prepared as part of the master thes is called " Effect of The Body Image and Body Katex on Women's Clothing Selection and AppreciationWith Investigation of Te Structual Equation Model" (Yıldırım, Berna, 2011) completed with in Gazi University's Educational Sciences Institute. 
emphases place on the body's characteristics have all introduced the concept of the "Body Image", which is the socio-psychological aspect of the body.

In the study they made of "Body Image", "Body Cathexis" and "Body Measurements" Chattaraman and Rudd (2006) defined Body Image as "The socio-psychological aspect of the body, which occupies an important place for women in clothing aesthetics."

Even though Body Image is a complex and theoretical concept, it is very much present in current life both consciously and unconsciously. Every expert treats the concept of Body Image differently according to their own area of expertise. The fact that this concept is used in many fields has led to the emergence of many different definitions.

Schilder's definition of Body Image in 1935 as, "the mental picture we paint of our own bodies; it is how our bodies appear to us" (qtd. in Franklin, 1996) may be interpreted as the concept of Body Image not only encompassing the individual's own individual or psychological investments.

Not only does clothing have the ability to put across the meaning it harbors through visual communication, it also possesses an aspect that enables women to appear as they imagine themselves to be, and this has been explained not only in the definitions above but also in the literature. Rudd and Lennon (2001) stressed that body image was influential in the formation of clothing aesthetics and that clothing and body fit were important. They expressed the need for body image to be treated as a phenomenon unique to the person who was influencing the aesthetics of appearance. There is no doubt that clothing has become a vital necessity that reflects women's personal characteristics, expresses their status and projects their mood. Nor can the contribution it makes to aesthetic appearance be denied. This is because the forms, colors, fabrics, stances and concepts that express particular cultures are what constitute fashion and they all exhibit wild changes as a result of concerns about aesthetic appearance (Y1ldirim, 2011: 1).It is known that fashion, which is equated with clothing, is an important factor in clothing preferences. The reason why fashion holds the masses under its sway despite being fleeting and seasonal stems from its inherent originality and its quality as a social phenomenon. This is because while meeting people's innate desires to be attractive, be different, impress others and be confident, originality also fulfills such social wants as identity, status, belonging to a specific group and adherence to fashion (Koca, Vural and Koç, 2013:56)

For women who express a flaw, be it actual or imagined, somewhere in their bodies clothing and the right choice of clothing is considerably important. In the rapidly changing field of fashion it is thought that aesthetic concerns and other similar concepts have introduced the phenomenon of body awareness. People may have negative thoughts about parts of their 
bodies that may not be important to others or that appear normal to others but which from their own point of view are flawed, ugly and aesthetically displeasing. Therefore, women use clothes to reduce to a minimum the difference between their ideal appearance and their actual appearance, and to correct their image. This situation can be explained by the adoption and use of Western aesthetic values.Chattaraman and Rudd conjectured that individuals used clothing to capture Western aesthetics, to hide the body's negative qualities and to emphasize certain positive qualities (2006: 47). Jourard, (1958) stated that clothing is able to minimize the difference between an individual's ideal body image and the real one and that people can use clothing as an important device for achieving their ideal aesthetic appearance (qtd inRobinson, 2003: 25).

Women need to use clothing correctly and to define their bodies well in order to develop a positive body image. It is thought that clothing not only turns a women's body image positive, it can also be used as a means to achieve her ideal aesthetic image. Just as with fashion pioneering, fashion innovation and the qualities associated with clothing, so the body image too is a personal characteristic that affects the way we interact through clothing and the way we present the clothing on us (Rudd and Lennon, 2001).

By becoming a source in the use of clothing, the body has become an important area in the textile and clothing fields, which also include the relationship between body approval and such variables as clothing approval, self-confidence and shopping (Feather, Herr, and Ford, 1997; Ford and Drake, 1982; LaBat and DeLong, 1990; Lennon and Rudd, 1994; Shim, Kotsiopulos, and Knoll, 1991; Rudd\&Lennon, 2001; Yildirim: 2011, Koca and Koç, 2016).

It is thought that clothing is an indispensable asset for the body. Instead of the thought of how appearance is perceived by others when choosing clothing, we are presented today with a fashion phenomenon in which a women can use clothing to create an image that is unique to her and appropriate to her body.

This study was formulated with the aim of understanding the powerful bond that exists between image and choice of clothing, a bond where clothing occupies an important place when it comes to women being able to possess a good image and powerful self-confidence and where they can minimize the difference between their ideal appearance and their actual one by using the aesthetic adaptation qualities inherent in clothing.

Two fundamental ideas underlie this choice of research topic:

1. The way that women express their body images and their clothing preferences;

2. The idea that there is a direct correlation between body image and clothing preferences. Additional aspects of the study are the level of self- 
confidence in clothing preferences and the effects of demographics on women's body images. The study aims to verify the notion that there is a direct correlation between body image, clothing preferences and demographics.

On examination of previous studies on the subject it can be said that the concept of body image developed together with personal perception. It is known that perceptional concepts are also psychological. SEM is particularly used in the scientific fields of psychometrics, psychology, sociology, marketing and education for evaluating the relationships between variables and testing conceptual models (Tezcan, 2008). This being so, SEM was considered appropriate for evaluating the data obtained in the study and thus it was used.

This study was formulated with the goal of stressing the importance of the relationship between body image and clothing in women's clothing preferences. In this study, which was analyzed using a Structural Equation Model (SEM) set up by the researchers, the goal is to determine the way women perceive and express their body image and clothing preferences, to determine what the direct effects of women's body image are on selfconfidence when choosing what to wear; also to determine the effects of "demographics" on women's clothing choices, and to determine the relationship and harmony between demographic variables.

\section{Material and Method}

The model developed by the researchers includes two interdependent variables (verbal and visual preferences in clothing), two directly independent variables (verbal and visual images) and five indirectly independent variables (employment status, age, location, level of education, body mass index - BMI).

Table 1. Sample Characteristics

\begin{tabular}{|c|c|c|c|}
\hline \multirow[t]{5}{*}{ Age } & & $\mathbf{n}$ & $\%$ \\
\hline & Young & 59 & 39.3 \\
\hline & Middle Age & 48 & 32.0 \\
\hline & Middle Aged & 43 & 28.7 \\
\hline & Total & 150 & 100.0 \\
\hline \multirow[t]{4}{*}{ Place } & Province & 57 & 38.8 \\
\hline & District & 34 & 22.7 \\
\hline & Village & 59 & 39.3 \\
\hline & Total & 150 & 100.0 \\
\hline \multirow[t]{5}{*}{ Education Level } & illiterate & 3 & 2 \\
\hline & Primary education & 72 & 48 \\
\hline & High School & 21 & 14 \\
\hline & College & 54 & 36 \\
\hline & Total & 150 & 100.0 \\
\hline \multirow[t]{3}{*}{ Job Statue } & Employe & 45 & 30 \\
\hline & Unemployed & 105 & 70 \\
\hline & Total & 150 & 100.0 \\
\hline
\end{tabular}


A pilot study was carried out on 60 women living within Konya province limits using the scale that had been developed in order to test the validity and the reliability of the questionnaire and the questions. Once the results were seen the main test was carried out. The study was carried out on 150 women (Y1ldirım, 2011).

Accuracy was calculated as:

$$
n=\frac{Z^{2} \sigma^{2}}{D^{2}}=\frac{1.96^{2} 38.265^{2}}{1^{2}}=147
$$

Where $\mathrm{D}=1$ and the highest variance or changeable variable at $95 \%$ is "Visual Clothing Preference." (Semiz, 2011). In this case, 150 women were tabulated by province, district and village and the study was carried out by weighting according to demographic variables.

This study covers 150 women aged 18-50 living within Konya province limits. The pool was split into three layers - province center (city), districts, villages. The plan was to choose 50 women from each layer. This study put the questionnaire to 10 women each in the one province center, five districts and five villages that were randomly selected. The study applied weighting functions according to level of education, profession, age group and location lived in the longest.

\section{Design}

When the researchers were formulating the basic problem asked in the study they took as their baseline the idea that both women's own body image perceptions and demographic characteristics affected their choices in what to wear. In connection with the literature that was studied, the conceptual background plan for those factors affecting the verbal and visual clothing choices was worked on. In other words, the study's problem was determined by means of the conceptual findings in the relevant literature. The Structural Equation Model (SEM) that has been used effectively in recent years was applied in order to determine the degree of influence for those factors affecting clothing choices and to demonstrate the interaction between these factors. SEM analysis determines not only direct impact between variables but also shows indirect impacts among variables. Therefore, SEM is more preferable than regression analysis. SEM model consists of depended variables and also direct and indirect independent variables (Y1ldirım, 2011).

\section{Questionnaire}

In the questionnaire that was prepared as a tool for measurement, image levels were determined both verbally and visually because it was thought that visual perception and verbal perception are different. Verbal 
image was measured according to the answers givenand in adherence with the level of acceptability of the statements given in the 5-point Likert System. Visual image was measured by means of the figure that was chosen from the shapes that were displayed (Yildırım, 2011).

Preference in clothing was measured using both a verbal and visual approach in the questionnaire, which was prepared as a tool for measurement. It is thought that visual perception and verbal perception are different. Verbal preference in clothing was measured according to the answers given and in adherence with the levels of acceptability for the statements given in the 5-point Likert System. For visual preference in clothing the figures used in the images that were presented were the same as used by Zhumagaziyevaat all (2010) in the scale she developed in her research in 2009 (Yildirim, 2011).

\section{Results}

Verbal and visual preferences in clothing were affected by verbal descriptions or visual images as well as by demographic factors such as employment status, age, place, level of education and body mass index.

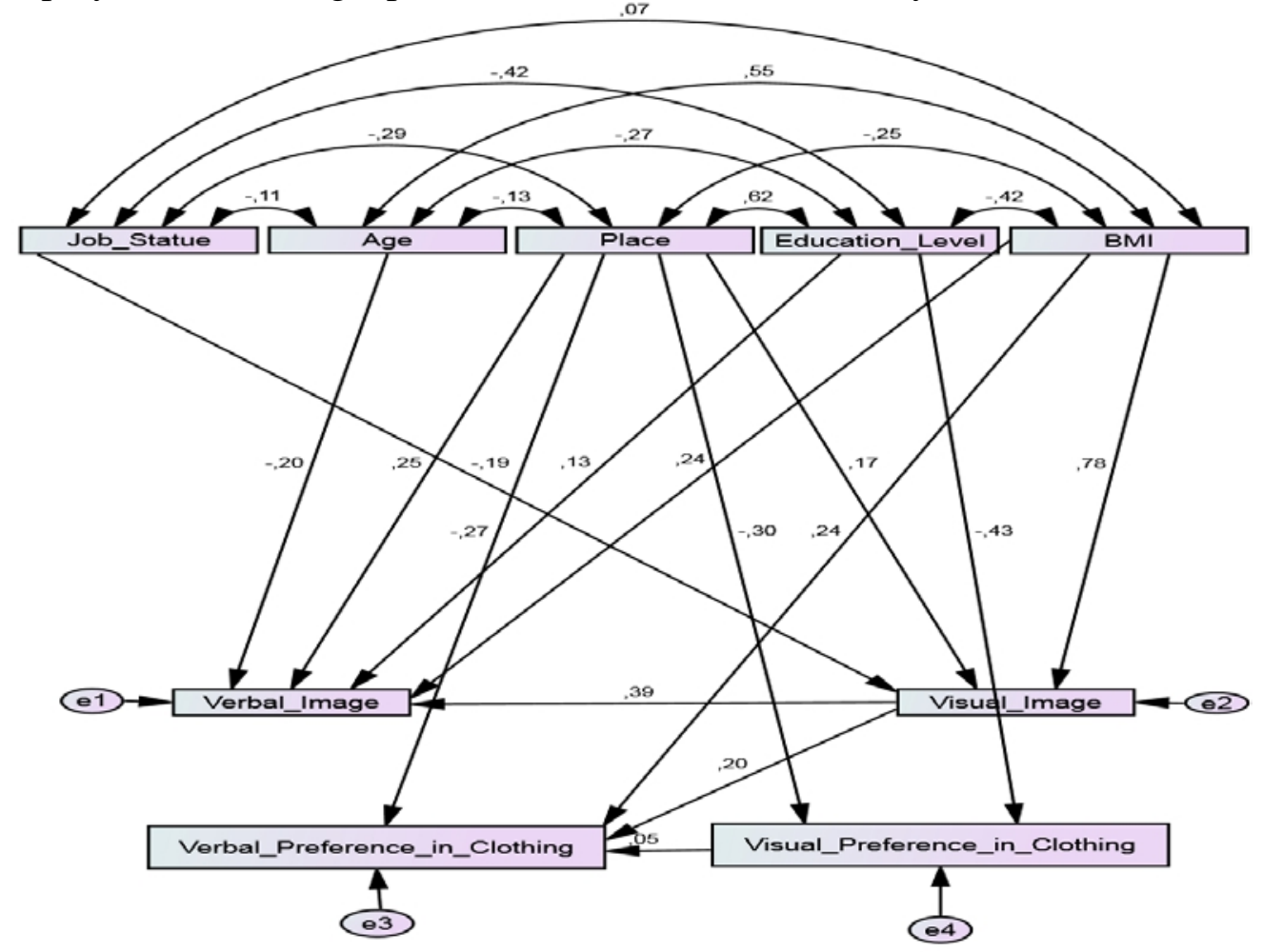

Figure 1: The Structural Equation Modellıng 
The direct, indirect and cumulative effects of independent variables on verbal or visual preferences in clothing were evaluated by Structural Equation Modeling (SEM) using AMOS with SPSS. The validity of the SEM evaluation was determined with the following values: Chi Square $=7,705$, Degree of Lattitude $=12$ and $p=0,808$. Default Model Fit Index Values are RMSEA $=0,000, \mathrm{CFI}=1,000, \mathrm{NFI}=0,986, \mathrm{CMIN} / \mathrm{DF}=0,642$.

The direct, indirect and cumulative effects in the model's structural relationships are presented in the tables. The association variables were assessed in terms of Visualand Verbal Preference and Visual and Verbal Images.

Table 2. Standardized Direct Effects (Group number 1 - Default model)

\begin{tabular}{cccccccc}
\hline & $\begin{array}{c}\text { Education } \\
\text { Level }\end{array}$ & BMI & $\begin{array}{c}\text { Job } \\
\text { Status }\end{array}$ & Place & Age & $\begin{array}{c}\text { Visual } \\
\text { Preference } \\
\text { In Clothing }\end{array}$ & $\begin{array}{c}\text { Visual } \\
\text { Image }\end{array}$ \\
\hline $\begin{array}{c}\text { Visual Preference } \\
\text { in Clothing }\end{array}$ &,- 432 &, 000 &, 000 &,- 303 &, 000 &, 000 &, 000 \\
\hline $\begin{array}{c}\text { VerbalPreference } \\
\text { in Clothing }\end{array}$ &, 000 &, 242 &, 000 &,- 274 &, 000 &, 047 &, 196 \\
\hline Visual Image &, 000 &, 779 &,- 194 &, 169 &, 000 &, 000 &, 000 \\
\hline Verbal Image &, 134 &, 237 &, 000 &, 254 &,- 202 &, 000 &, 395 \\
\hline
\end{tabular}

As can be seen in Table 2, The level of education was not determined to have a direct effect on verbal preference or visual image but did have a direct effect on visual preference $(b=0.432)$ and verbal image $(b=0.134)$. While BMI had do direct effect on visual preference it was seen to affect verbal preference $(b=0.242)$, visual image $(b=0.779)$ and verbal image $(b=0.237)$. Employment status does have a direct effect on visual image and this impact was measured as $(b=-0.194)$. Place of residence is the only factor that directly affects the four variables: visual preference $(b=-0.303)$, verbal preference $(b=-0.374)$, visual image $(b=0.169)$ and verbal image $(b=$ 0.254). Remarkably, "Place of residence" has a positive effect on image but a negative effect on preference. Age is seen to have a direct influence on verbal image measured as $(b=-0.202)$. Visual preference has a limited direct impact on verbal preference $(b=0.047)$ while visual image has a direct impact on verbal preference $(b=0.196)$ and verbal image $(b=0.395)$

Table 3. Standardized Indirect Effects (Group number 1 - Default model)

\begin{tabular}{ccccc}
\hline & $\begin{array}{c}\text { Education } \\
\text { Level }\end{array}$ & BMI & $\begin{array}{c}\text { Job } \\
\text { Statue }\end{array}$ & Place \\
\hline Visual Preference in Clothing &, 000 &, 000 &, 000 &, 000 \\
\hline Verbal Preference in Clothing &,- 019 &, 023 &,- 010 &,- 011 \\
\hline Visual Image &, 000 &, 000 &, 000 &, 000 \\
\hline Verbal Image &, 000 &, 065 &,- 029 &, 008 \\
\hline
\end{tabular}


As can be seen in Table 3, the level of education has only a indirect effect on verbal preference $(b=-0.019)$. BMI exhibited an indirect influence over verbal preference $(b=0.023)$ and an indirect influence over verbal image $(b=0.065)$. Employment status is seen to affect verbal preference $(b=$ $-0.010)$ and verbal image $(b=-0.029)$. Place of residence has a significant yet indirect effect on verbal preference and verbal image being $(b=-0.011)$ and $(b=0.008)$ respectively.

Table 4. Standardized Total Effects (Group number 1 - Default model)

\begin{tabular}{cccccccc}
\hline & $\begin{array}{c}\text { Education } \\
\text { Level }\end{array}$ & BMI & $\begin{array}{c}\text { Job } \\
\text { Status }\end{array}$ & Place & Age & $\begin{array}{c}\text { Visual } \\
\text { Prefence } \\
\text { Clothing }\end{array}$ & Visual \\
Image \\
\hline $\begin{array}{c}\text { Visual Preference } \\
\text { in Clothing }\end{array}$ &,- 432 &, 000 &, 000 &,- 303 &, 000 &, 000 &, 000 \\
\hline $\begin{array}{c}\text { Verbal Preference } \\
\text { in Clothing }\end{array}$ &,- 020 &, 394 &,- 038 &,- 255 &, 000 &, 047 &, 196 \\
\hline Visual Image &, 000 &, 779 &,- 194 &, 169 &, 000 &, 000 &, 000 \\
\hline Verbal Image &, 134 &, 544 &,- 076 &, 320 &,- 202 &, 000 &, 395 \\
\hline
\end{tabular}

As can be seen in Table 4, Overall, level of education does not affect visual image at all but was determined to affect visual preference ( $\mathrm{b}=$ $0.432)$, verbal preference $(b=-0.20)$ and verbal image $(b=0.134)$. BKI overall has not effect on preference but was determined to affect verbal preference $(b=.394)$, visual image $(b=0.779)$ and verbal image $(b=0.544)$. Employment status overall affected verbal preference $(b=-0.038)$, visual image $(b=-0.194)$ and verbal image $(b=-0.076)$. Place of residence also affect the four associated variables overall: visual preference $(b=-0.303)$, verbal preference $(b=-0.255)$, visual image $(b=0.169)$ and verbal image $(b=$ $0.320)$. Age was seen to have an impact overall being $(b=-0.202)$. Visual preference did have an overall effect on verbal preference $(b=30.47)$. Visual image had an overall effect on verbal preference $(b=0.196)$ and verbal image $(b=0.395)$.

\section{Discussion and Conclusion}

Clothing is a phenomenon that is shaped by the influence of social factors in women's lives. We can say that our clothing preferences and our likes have an important effect on shaping our appearance and the way we behave in the many fields of our lives. Just as clothing preference can exhibit change depending on our attitude and behavior so is it also influenced by developments in the means of information and communication, and by perceptions of social life and by changes in the socio-cultural, economic and political fields. According to Koca (2008:178),behavior and traditional elements which constitute cultural structures of individuals living in different 
social environments, individual's views on fashion are also affected by the social environment they live in, their age, sex and economic conditions.

But most important of all is how clothing preferences change according to the perception of the body. In other words, clothing preferences can be shaped by psychological and social factors. At the same time, they can change depending on the body's makeup.

Using the model developed in this study an attempt was made to determine the degree to which body image influences women's choice of clothing and what they like. The women used as the sample group for this study all live within Konya provincial limits, and they lent their support to the study by answering the measurement device prepared by the researcher.

\section{How Women Perceive and Express Their Body Image and Clothing Preferences}

It is thought that there are two forms of perception and that these are expressed as and called visual and verbal perception. The body image, which is the subject of the study, is all about perception because researchers have define the body image as "a person's perception of him or herself (Doğan, 1992). For this reason, body image was measured in two ways in this study and these measurements were named visual image and verbal image by the researcher.

In determining the visual measurements for body image the sample group women were shown figures of women categorized from skinny to overweight. They were asked which figure they thought best applied to them and this was measured. In determining the verbal measurements of body image the sample group women were given sentences relating to parts of the body and an attempt was made to measure their thoughts about their bodies. The results showed a difference between these two measurements of body image.

While the visual image and verbal image expressions were seen not to match each other, another finding of considerable importance was determined. It was seen that as they did not match, the verbal image influenced the choice of visual clothing preference while on the other hand the visual image determined the verbal choice of clothing. The existence of the mismatch between images as well as the height of the relationship stems from women being bolder in stating their visual images. It was determined that in their verbal images they made themselves out to be slimmer when compared to their visual images. Women verbally express their weight as being lower than the visual body image, or they prefer to conceal it. It can be seen that the expressions of visual and verbal perception on the same scale are different. In other words, as Fallon stated, the body image as perceived by the person may or may not exactly represent that person's 
actual size measurements. To put it another way, a person may consider him or herself as being smaller or larger than they actually are (Fallon, 1990).

The measurement device had both visual and verbal sections in order to measure clothing preferences. Although a relationship was seen between the visual and verbal preferences of the women in the study, it was determined that the match was to some degree weaker. It was observed that in clothing preferences women did not possess the same self-confidence in verbal and visual terms, that their visual self-confidence was one degree higher than their verbal self-confidence and that they did not match one another, yet they were related. It is thought that this situation is the result of the women either changing their statements about some topics and ideas depending on their own perceptions when verbally describing their preferences and/or that they were unable to express themselves clearly. It was determined that verbal image is one of the most important factors affecting visual clothing preferences. Visual image was not seen to influence clothing preferences, while it was determined that visual image is significant in verbal clothing preferences.

\section{How Women's Body Images Directly Affect Their Self-Confidence in Clothing Preferences:}

While a relationship between clothing preferences and body image was expected, it was determined that a relationship existed only between visual clothing preferences and the verbal image, and between verbal clothing preferences and the visual image. The results showed that body image is a quality unique to the person who is influencing women's clothing preferences and their likes.

Even though women may possess a normal degree of body image as determined by the measuring device, they still have parts of their bodies that they are unhappy with and feel the need to cover or conceal those area using clothes. Women who think they have an overweight body image stated they had lower self-confidence than other women in their clothing preferences. This is why they choose garments that do not emphasize the body's lines and feel the need cover or conceal those parts of their bodies that they are not happy with. When women with slim body images in verbal clothing preferences are choosing clothingthey are seen to have high self-confidence, meaning they prefer clothes that are revealing and that require confidence to wear instead of garments that camouflage their bodies.

\section{How Demographic Characteristics Affect Women's Body Images:}

As the person is a social being living in a social environment, it is conceived that the traditions and life styles in the environment the person lives are also important factors that shape the person's aesthetic values (Koca 
and Seçim, 2016: 83).In the relationship between age and image it was determined that as people grow older they perceive themselves as having put on weight. Statistically speaking, the relationship between age and visual image is important yet no significant relationship was found between age and verbal image.

It may be said that women who live in the districts and villages have body images that say they are not overweight, or that their perceptions of being overweight are different when compared to women living in the city. We can say that even when overweight they were happy with their bodies.

Social environment changes as the level of education increases. As their social environment changes so women state they want to be slim when expressing their body images. Statistically speaking, there is also a significant relationship between level of education and verbal image. However, even though we can say that the level of education does affect visual image not statistical significance was found.

It turned out that for "employment status" there was a difference between the visual and verbal expressions of body image. It was determined that employment status did not affect women's verbal images.

When looking at the relationship between BMI and visual image, women whose BMI was above normal did not perceive themselves as being overweight. When looking at the relationship between BMI and verbal image, however, it was determined that overweight and extremely overweight people expressed their weight as being normal and over. This difference stems from difference in manners of expression.

\section{Relationship and Harmony Among Demographic Variables:}

A significant relationship was seen between "Age" and "Level of Education." The younger women were mainly university educated while the middle-aged women said they were high-school education and the elder women said they only had a primary school education. No significant difference was seen among the age groups with respect to "Employment Status." Regardless of age group, 60-70 percent of women said they were unemployed. When the relationship between age and BMI was looked at it was concluded that most of the women representing the women within the province's borders were of the ideal weight. In the relationship between "Place of Residence" and "Level of Education" it was seen that almost all the illiterate and primary school educated women lived in villages. In the relationship between "Place of Residence" and "Employment Status" there was an increase in employment in the province's center, meaning the city. In the relationship between "Place of Residence" and BMI the women who lived in the villages were unhappy with being slim while the women who lived in the city were unhappy with being overweight. An extremely 
significant relationship was observed between "Level of Education" and "Employment Status." As the level of education increased so did the proportion of women employed. When looking at the effect of "Employment Status" on BMI it was determined that employed women paid more attention to their BMI than unemployed women and that unemployed women did not care much about BMI.

\section{The Effects of Demographics on Women's Self-Confidence in Clothing Preference}

It was determined that of those factors that indirectly affected clothing preference, age, place of residence, level of education, employment status and BMI values were all related to visual clothing preference. Of these factors the only one having a significant impact on verbal clothing preferences was employment status. As the employment status for women also included the women in the villages and districts it is possible to interpret these data as: "No significant difference was seen in clothing preferences with respect to the working environment." It is known that indirect factors do not have a direct impact on clothing preferences but that they do affect the verbal and visual image.

It was seen that age, employment status and BMI values had a significant impact on visual image and this changed considerably for verbal image.

BMI is related to all the other demographic variables, to image values and directly to clothing preferences. Level of education is related to all other demographic variables, image values and directly to clothing preferences.

In conclusion, it was determined that the values of "Level of Education" and BMI, which are demographic variables, did affect clothing preferences in different ways depending on the values for the direct variables of "Visual and Verbal Image."

Given the conclusions of the findings obtained through the SEM model developed here with the purpose of determining the degree to which body image affected women's clothing preferences and likes, the following can be suggested:

$\checkmark \quad$ The data obtained in the survey may be used as a reference for textile and body image studies. Women's clothing preferences and likes can be a sign post whenever body image is taken into account.

$\checkmark \quad$ If clothing outlets pay attention to body image based on the data obtained in this survey it could help them increase diversity in accordance with customer potential.

$\checkmark \quad$ The findings obtained may form a source of reference in determining the link between the body's physical and socio-psychological characteristics 
and women's clothing preferences by giving direction to body image and clothing studies.

$\checkmark \quad$ An opinion may be arrived at with respect to the reasons underlying the similarities in the participants' reactions concerning the relationship between women's attitudes on clothing preferences and likes, and body measurements and body image.

$\checkmark \quad$ As this study is based on the views of women aged from 18 to 50 it may be used as a source of reference for new research into clothing products incorporating different genders and age groups.

\section{References:}

1. Chattaraman, V. \& Rudd N. A., 2006,Preferences For Aesthetic Attributes İn Clothing As A Function Of Body Image, Body Cathexis And Body Size, Clothing and Textiles Research Journal,Vol:2, pp.46-56. Doi: 10.1177/0887302X0602400104

2. Doğan, O.\&, Doğan, S., 1992,Çok Yönlü Beden Sel-Self İlişkileri Ölçeği El Kitabı. Cumhuriyet University Faculty of Medicine: Sivas.

3. Fallon, A. E., 1990,Culture in The Mirror: Sociocultural Determinants Of Body İmage. In Body İmages: Development, Deviance and Change. Edited by T.F. Cash and T. Pruzinsky, New York: The Guilford Press.

4. Feather, B.L.and Herr, D.G., and Ford, S., 1997, Black and white female athletes' perceptions of their bodies and garment fit. Clothing and Textiles Research Journal, Vol:15(2), pp.125-128. doi: 10.1177/0887302X970150020.

5. Franklin, E., 1996, Dynamic Alignment Throught. Imagery Categorization.The Body Image Alligment, Human Cinetics, Champaign, USA.

6. Ford, I. M., \&Drake, M. F., 1982,“Attitudes Toward Clothing, Body And Self: A Comparison Two Groups”. Home Economics Research Journal, Vol:11, pp. 189-196.

7. Jourard, S.M., 1958, Personal Adjustment. New York: Macmillan.

8. Koca E,\& Seçim E., 2016, Reflection of Socio- CulturalExperiences of Fashion Design StudentstoTheirCollections, X InternationalFashion Conference, Unıversidad De Navarra, April 20th and 21st, 2016, Pamplona, Spain.81-94

9. Koca, E. \& Koç F., 2016, “A Study of Clothing Purchasing Behavior By Gender with Respect to Fashion and Brand Awareness”,European Scientific Journal, Vol: 12 (7), pp.234-248. doi: 10.19044/esj.2016.v12n7p234.

10. Koca E. Vural T. \&Koç F., 2013, An Evaluation Of Consumer Tendencies Towards Hedonistic Shopping For Clothes, EJRE- 
European Journal of Research on Education, Special Issue: Human Resource Management,pp. 54-64

11. Koca E., 2008, Comparison Of Viewpoints Towards Fashion Among University Students In Different Countries, .TekstilveKonfeksiyon, Vol: 18, No: 3, pp: 174-184

12. Labat, K.L.,\&Delong, M.R., 1990,"Body cathexis and satisfaction with fit of apparel”. Clothing and Textiles Research Journal, Vol: 8 (2), pp. 43-48. doi: 10.1177/0887302X9000800206.

13. Lennon, J.\&Rudd, N.A., 1994,Linkages Between Attitudes Toward Gender Roles, Body Satisfaction, Self- Esteem and Appearance Management Behaviors in Women. Family and Consumer Sciences Research Journal,Vol:23, pp. 94-117. doi: 10.1177/1077727X94232002

14. Lennon, J.\&Rudd, N.A., 2001.,Self-Schema Or Self-Discrepancy? Which Best Explains Body İmage? Clothing And Textiles Research Journal,Vol:19 (4), pp. 171-184. Web: Http://Ctr.Sagepub.Com/Cgi/Reprint/19/4/171. doi: 10.1177/0887302X0101900403.

15. Robinson T.R., 2003, Clothing Behavior,Body Cathexis, And Appearance Management Of Women Enrolled İn A Commercial Weight Loss Program (Doctoral dissertation, Blacksburg, Virginia).

16. Semiz, M., 2011,Örnekleme Yöntemleri, Bilgi Ofset: Konya

17. Schilder, P., 1935, The Image and Appearance of the Human Body: Studies in the Constructive Energies of the Psyche. K. Paul, Trench, Trubner\& Company Limited, 1935.

18. Shim, S.\& Kotsiopulos, A., and Knoll, D.S., 1991, “Body cathexis, clothing attitude, and their relations to clothing and shopping behavior among male consumers", Clothing and Textiles Research Journal, Vol: 9 (3), pp.35-44. doi: 10.1177/0887302X9100900306

19. Tezcan, C., 2008,Yapısal Eşitlik Modelleri, (Master Thesis) Hacettepe University / Department of Statistics.: Ankara.

20. Y1ldırım, B., 2011, Beden İmajı ve Beden Kateksinin Kadınların Giysi Seçimi ve Beğenisi Üzerindeki Etkileri'nin Yapısal Eşitlik Modeli ile Analizi (Master Thesis) Gazi Universty/ Institute of Education Sciences. Ankara.

21. Zhumagaziyeva, A \& Koç F. 2010, “Kültürel Etkileşimde Kadınların Giysi Alışkanlıklarındaki Değişimin Mahramiyet Açısından İncelenmesi (Kazakistan ve Türkiye Örneği)', ,NWSA- e Journal of New World Sciences Academi (International peer-reviewed ejournal), Vol:5 ( 2), pp.114-131 